\title{
Analyzing how to reduce financial reliance of retirement organization of municipality of Tehran on financial assistance of municipality
}

\author{
Asadollah Afshary ${ }^{a^{*}}$ and Mohammad Sadegh Mohagheghynia ${ }^{\mathrm{b}}$
}

${ }^{a}$ Assist. Prof. \& Faculty Member, Department of Commercial Management, School of Management, Tehran North Branch, Islamic Azad University (IAU), Tehran, Iran

${ }^{b}$ M.Sc. Student, Department of Commercial Management, School of Management, Tehran North Branch, Islamic Azad University (IAU), Tehran, Iran

\section{CH R O N I C L E}

Article history:

Received October 28, 2013

Received in revised format

25 November 2013

Accepted 29 January 2014

Available online

January 312014

Keywords:

Pension funds

Retirement plan

Municipality

\section{A B S T R A C T}

\section{Introduction}

Pension funds play essential role for retirement plan of shareholders of listed and private firms. A pension is considered as a contract for a fixed sum to be contributed on a regular basis to a person when he/she retires. A retirement plan is an arrangement to provide retired people with a fixed income when they are no longer earning a steady income from employment. There are various types of pensions such as defined benefit plans, defined contribution plans, as well as several others. Pensions are essentially important to the stock market where big institutional investors dominate (Medina Giacomozzi et al., 2013). Mohan and Zhang (2014) presented a comprehensive investigation on the determinants of public pension fund investment risk and presented various findings. Unlike private pension plans, public funds undertake more risk if they are underfunded and maintain lower investment returns in the previous years. In January 2008, the Economist reported that Morgan Stanley predicted that pension funds worldwide hold well over US\$20 trillion in assets, the biggest

*Corresponding author. Tel: +98-912-2356048

E-mail addresses: taha_3137@yahoo.com (A. Afshari) 
for any category of investor ahead of mutual funds, insurance companies, currency reserves, sovereign wealth funds, hedge funds, or private equity. There are literally various types of pension funds such as private and public with various policies (Davis, 1998; Mitchell, 1998). The public fund is regulated under public sector law while the private pension fund is regulated under private sector law. In some countries, it is difficult to distinguish between public or government pension funds and private pension funds.

The existence of feedback impacts between volatility and institutional investor holdings has been extensively investigated for the United States. Fernandez (2014) contributed to the literature by studying the issue for Pension Fund Administrators (PFAs) in Chile. The author reported that, first, an increase in PFAs' stock holdings translated into a mild impact on stock return volatility. In addition, an increase in stock return volatility could lead to a moderate decrease in PFAs' stock holdings, implying PFAs' preference for safer stocks. Yao et al. (2013) developed an optimal investment problem of a scheme member by considering stochastic inflation under the Markowitz mean-variance criterion. In addition, they studied a more general market with multiple assets, which could all be risky. They derived the associated Hamilton-Jacobi-Bellman (HJB) equation by implementing the Lagrange method and stochastic dynamic programming methods.

An et al. (2013) discussed different issues for detecting various factors reducing any possible risk associated with pension funds. Jackowicz and Kowalewski (2012) provided some insight on the effect of supervisory board structure as an internal governance mechanism on privately defined contribution pension fund performance in Poland. They reported that the chairman, as a motivated insider, plays an essential role in detecting fund performance. The results also stated that outsiders could positively influence fund performance. However, the insider professional knowledge outweighed the advantages of having motivated outsiders on the supervisory board. Their results indicated that both the composition of the supervisory board and the motivation and knowledge of its members were important in explaining pension fund performance. However, other governance factors had no effect on fund performance. Aglietta et al. (2012) gave some insight on pension funds' sources of performance and explained that taking explicit account of market movement could change the results, substantially. Yao et al. (2014) studied an asset allocation problem for defined contribution pension funds with stochastic income and mortality risk under a multi-period meanvariance framework.

\section{The proposed study}

In this paper, we try to find possible action to reduce the dependency of Tehran municipality pension fund to external support. The proposed study of this paper considers the following three hypotheses,

1. It is possible to reduce the dependency of Tehran municipality pension fund to municipality organization by reducing liabilities of the fund.

2. It is possible to reduce the dependency of Tehran municipality pension fund to municipality organization by making necessary changes on methods and procedures.

3. It is possible to reduce the dependency of Tehran municipality pension fund to municipality organization by designing new procedures.

The proposed study designs a questionnaire in Likert scale in six categories including administration and supportive affairs (ASA), stability in retirement regulations (SRR), type of pension fund (TPF), revenue management (RM), improvement in investment strategies (IIS), economic policy and central bank regulations (EP-CPR). Table demonstrates distribution of the questions of the survey, which covers all six categories. 
Table 1

The summary of the responses

\begin{tabular}{|c|c|c|c|c|c|c|}
\hline Question & Category & Very low & Low & Average & High & Very high \\
\hline 1 & ASA & 0 & 4 & 8 & 12 & 12 \\
\hline 2 & ASA & 0 & 0 & 0 & 20 & 16 \\
\hline 3 & SRR & 0 & 0 & 12 & 8 & 16 \\
\hline 4 & SRR & 0 & 4 & 12 & 16 & 4 \\
\hline 5 & ASA & 0 & 0 & 0 & 16 & 20 \\
\hline 6 & SRR & 0 & 0 & 20 & 12 & 4 \\
\hline 7 & SRR & 0 & 0 & 0 & 16 & 20 \\
\hline 8 & SRR & 0 & 4 & 4 & 20 & 8 \\
\hline 9 & TPF & 0 & 0 & 8 & 20 & 8 \\
\hline 10 & ASA & 0 & 0 & 8 & 24 & 4 \\
\hline 11 & $\mathrm{RM}$ & 0 & 0 & 4 & 4 & 28 \\
\hline 12 & RM & 0 & 4 & 4 & 20 & 8 \\
\hline 13 & ASA & 0 & 0 & 4 & 24 & 8 \\
\hline 14 & SRR & 0 & 4 & 12 & 12 & 8 \\
\hline 15 & SRR & 4 & 0 & 12 & 4 & 16 \\
\hline 16 & SRR & 8 & 8 & 4 & 12 & 4 \\
\hline 17 & EP-CPR & 0 & 0 & 20 & 8 & 8 \\
\hline 18 & SRR & 0 & 0 & 12 & 16 & 8 \\
\hline 19 & EP-CPR & 4 & 8 & 0 & 12 & 12 \\
\hline 20 & TPF & 0 & 0 & 4 & 28 & 4 \\
\hline 21 & TPF & 0 & 4 & 12 & 20 & 0 \\
\hline 22 & IIS & 0 & 0 & 0 & 20 & 16 \\
\hline 23 & EP-CPR & 0 & 4 & 4 & 12 & 16 \\
\hline 24 & SRR & 0 & 0 & 4 & 24 & 8 \\
\hline 25 & IIS & 0 & 0 & 8 & 12 & 16 \\
\hline Sum & & 16 & 44 & 176 & 392 & 272 \\
\hline Percent & & 1.77 & 4.88 & 20 & 43.55 & 29.77 \\
\hline
\end{tabular}

In order to study the relationship among various components of the theses six categories, the proposed study uses Spearman correlation ratio and Table 2 demonstrates the summary of our findings.

Table 3

The summary of Spearman correlation ratio

\begin{tabular}{cccccccc}
\hline & Correlation & ASA & SRR & TPF & RM & IIS & EP-CPR \\
\hline ASA & r & - & 0.894 & 0.667 & 0.975 & 0.866 & 0.872 \\
& Sig. & - & 0.02 & 0.109 & 0.002 & 0.029 & 0.027 \\
\hline SRR & r & 0.894 & - & 0.459 & 0.918 & 0.968 & 0.803 \\
& Sig. & 0.02 & - & 0.218 & 0.014 & 0.003 & 0.051 \\
\hline TPF & r & 0.667 & 0.459 & - & 0.689 & 0.667 & 0.895 \\
& Sig. & 0.109 & 0.218 & - & 0.101 & 0.109 & 0.020 \\
\hline RM & r & 0.975 & 0.918 & 0.684 & - & 0.889 & 0.895 \\
& Sig. & 0.002 & 0.014 & 0.101 & - & 0.022 & 0.02 \\
\hline IIS & r & 0.866 & 0.968 & 0.592 & 0.889 & - & 0.889 \\
& Sig. & 0.029 & 0.003 & 0.146 & 0.022 & - & 0.022 \\
\hline EP-CPR & r & 0.872 & 0.803 & 0.895 & 0.895 & 0.889 & - \\
& Sig. & 0.027 & 0.051 & 0.02 & 0.02 & 0.022 & - \\
\hline
\end{tabular}

As we can observe from the results of Table 3, there are strong relationships between different components. Therefore, we can examine three hypotheses of the survey.

\section{Conclusion and discussion}

The first hypothesis of the survey investigates whether it is possible to reduce the dependency of Tehran municipality pension fund to municipality organization by reducing liabilities of the fund or not. Based on the results of Table 2, there is a positive and meaningful relationship between the first 
and the second option, administration and supportive affairs (ASA), stability in retirement regulations $(\mathrm{SRR})(\mathrm{r}=0.894$, Sig. $=0.02)$ and we can conclude that the first hypothesis of the survey is approved. In other words, an increase in retirement regulations would help build an independent pension fund. The second hypothesis of the survey investigates whether or not it is possible to reduce the dependency of Tehran municipality pension fund to municipality organization by making necessary changes on methods and procedures. Based on the results of Table 2, there is a strong and positive relationship between the third and sixth items, type of pension fund (TPF) and economic policy and central bank regulations $(\mathrm{EP}-\mathrm{CPR})(\mathrm{r}=0.895$, Sig. $=0.02)$. Therefore, we can confirm the second hypothesis of the survey. Finally, the third hypothesis of the survey investigates whether or not it is possible to reduce the dependency of Tehran municipality pension fund to municipality organization by designing new procedures. Since there is a positive and meaningful relationship between fourth and fifth items, revenue management (RM) and improvement in investment strategies (IIS) we may conclude that it is possible to perform a good due diligence and setup new policy to build an independent pension fund.

\section{Acknowledgement}

The authors would like to thank the referees for their comments on earlier version of this paper.

\section{References}

Aglietta, M., Brière, M., Rigot, S., \& Signori, O. (2012). Rehabilitating the role of active management for pension funds. Journal of Banking \& Finance, 36(9), 2565-2574

An, H., Huang, Z., \& Zhang, T. (2013). What determines corporate pension fund risk-taking strategy?. Journal of Banking \& Finance, 37(2), 597-613.

Davis, E. P. (1998). Policy and implementation issues in reforming pension systems (No. 31). European Bank for Reconstruction and Development.

Fernandez, V. (2014). Stock volatility and pension funds under an individual capitalization-based system. Journal of Business Research, 67(4), 536-541.

Jackowicz, K., \& Kowalewski, O. (2012). Crisis, internal governance mechanisms and pension fund performance: Evidence from Poland. Emerging Markets Review, 13(4), 493-515.

Medina Giacomozzi, A., Gallegos Muñoz, C., Vivallo Ruz, C., Cea Reyes, Y., \& Alarcón Torres, A. (2013). Efecto sobre la rentabilidad que tiene para el afiliado la comisión cobrada por las administradoras de fondos de pensiones. Journal of Economics Finance and Administrative Science, 18(34), 24-33.

Mitchell, O. S. (1998). Building an environment for pension reform in developing countries. Social Protection, World Bank.

Mohan, N., \& Zhang, T. (2014). An analysis of risk-taking behavior for public defined benefit pension plans. Journal of Banking \& Finance, 40, 403-419.

Yao, H., Yang, Z., \& Chen, P. (2013). Markowitz's mean-variance defined contribution pension fund management under inflation: A continuous-time model. Insurance: Mathematics and Economics, 53(3), 851-863.

Yao, H., Lai, Y., Ma, Q., \& Jian, M. (2014). Asset allocation for a DC pension fund with stochastic income and mortality risk: A multi-period mean-variance framework. Insurance: Mathematics and Economics, 54, 84-92. 